\title{
The Taming of the Canaanite Woman: Con- structions of Christian Identity in the Afterlife of Matthew 15:2I-28, by Nancy Klancher
}

Studies of the Bible and Its Reception I | Berlin and Boston: de Gruyter, 20I 3 | ix + 3 I 5 pages | ISBN: 978-3-I I-032 I06-7 (hardcover) €99.95

This is an interesting title. Does it imply that this is a

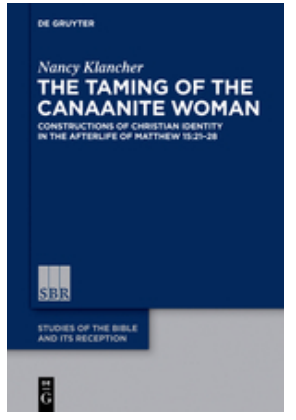
woman who needs taming? Or does it rather imply that the construction of Christian identity requires, or results in, her taming? The book is a revised version of Nancy Klancher's PhD thesis, accepted by the University of Pittsburgh in 20I2, and, for the most part, written in careful thesis style. It is an exploration of the Canaanite's afterlife that takes the reader into the world of Christian theologizing in all its liveliness, as again and again she becomes a tool in the debates, many of which blaze with acrimony. While the opening sentence, "Biblical interpretation is an essential tool in the inculcation of Christian identity and conduct" (I), sounds academically dispassionate, there is passion and ideological concern aplenty in the use of the Canaanite of Matt I 5:2 I-28, so that the interest for the reader becomes much wider than this one text and its female character. As Klancher admits, it is "the contentious collision of exegetical arguments and social realities" that is the subject of her study. Her aim is to explore "the how" of the process by which exegetes use the text to construct what they varyingly view as "normative Christian identities," with particular focus on "textual devices that interlock paranesis, the internalization of ideals, and the embodiment or enactment of norms" $(\mathrm{I}-2)$. The range of material accessed is impressive in its breadth. Not only are major and familiar figures such as Origen, Jerome, Ambrose, Augus- 
tine, John Chrysostom, Luther, and Calvin represented but many that were entirely new to me, such as fourth-century Ephrem of Nisibis, fifth-century Quodvultdeus, bishop of Carthage, and Ishodad of Merv, and Dhuoda of Septimania, both ninth-century. Altogether there are about fifty readings analysed, extending from the second to the twenty-first century, although the majority are pre-Reformation. The eight art works, showing the "many faces of the Canaanite Woman" make a fitting closure to the book.

The Introduction, appropriately for a thesis, includes a section on the history of interpretation and reception studies, with some trenchant criticism of eariier reception histories. It concludes with Klancher's own view of reception theory, largely influenced by Hans Robert Jauss, emphasizing the "historical effects of the text-reader event" (29). The quote from Anthony Thiselton, describing Jauss's approach, equally describes Klancher's theoretical position: "changing situations make their impact on successive readings and rereadings of texts. ... The history of effects is two-sided or bidirectional. ... Texts have a formative influence upon readers and society but changing situations also have effects on how texts are read" (29-30). At the same time, she notes the contribution of feminist theory with its "bedrock concept of socially constructed subjectivity" (32).

The chapters are ordered according to uses of the text rather than following a chronology. A significant divide is the anathema/exemplum contrastreadings of the woman as "other" as against those seeing her as a model of faith, the first of which encourages division, and the second "active spiritual development" (39). While chapter 2 is a study of early interpretations from the third to fifth centuries, with the Canaanite teetering, as a player, between "historically-grounded and spiritually-based paranesis" (58), chapter 3 focuses upon "anathema" readings from the ninth-century to the present day. Chapter 4 then turns to early "exemplum" readings, while chapter 5 studies "Protestant Readers from the Reformation to the Early 2oth Century." Chapter 6 then features some "Avatars of the Canaanite Woman." Current scholarship is left to five pages of the brief Epilogue, with concluding comments on the implications of the study regarding reception history in its final four pages. At times the chronological leaps were a little disconcerting, as in the direct move from sixth-century Epiphanius Scholasticus to John Hutton's I9I9 lecture at Glasgow University (I04-5), even if both are part of the chilling tradition of silencing "the Jews." At the same time, the careful historical settings served to strengthen the thesis, as well as providing fresh insights. Realizing the theological politics involved in Cranmer's setting the 
well-known prayer of "Humble Access" within the Eucharistic Prayer, for example, makes a difference: I now understand that this is not so much the grovelling of the penitent as a re-enactment of the Canaanite's "confidence and chutzpah" in a "protestant play of direct appeal to Jesus" in contrast to priestly mediation (266).

As the book's subtitle indicates, the concern is with the role of exegesis in forming Christian identity, so the texts explored are, for the most part, those of Christian writers, mostly early Church Fathers and later clergy, whose exegesis tends to slip or advance quite deliberately into paranesis, with the typical "we too" move. So Origen writes, "and we must surely believe that each of us, when he sins, finds himself in the territory of Tyre and Sidon" ( 56 ; Klancher's translation). Allegorically, for Origen, the Canaanite also becomes the soul transcending its irrational nature as it progresses towards God. What varies, of course, is the goal of the paranesis: sometimes essentially spiritual, sometimes as overtly political as the Rev Carlisle's use of the text in 1906 in support of a bill for the provision of meals for day-school children. A significant trajectory concerns the "lost sheep of Israel," with its many candidates: Jews, Gnostics, and whichever group within the Church was deemed "sinful" or worse. The chapter "Not the Gift but the Giver: Protestant Readers from the Reformation to the Early 2oth Century" introduces Luther and Calvin who typically turn the exegetical lens to focus on the grace of God, which falls upon the Canaanite, seen as sinful, needy yet faithful. The digression on the sharp antagonism between Calvin and Servetus provides a clear example of theology driving interpretation. For Servetus, the Canaanite meets Jesus and comes to faith spontaneously, but for Calvin that cannot be. She must have been schooled in doctrine through divine revelation: the agency must be God's, not the woman's. A view held as bedrock by the following five Protestant clergymen, from the seventeenth to the early twentieth century, illustrating how Protestant doctrine shaped biblical interpretation. The final chapter takes the paranetic aspect one stage further with a selection of texts that adopt the Canaanite's voice and persona. Klancher's thesis, following Jauss, is that these embody what the exegetical paranesis has attempted to instil. It is not so much the underlying theory, but rather the poignancy of the first reading here that stays with me. A ninth-century Carolingian mother, Dhuoda of Septimania, kept in social isolation by her estranged husband, her children removed from her, writes a manual of instruction for her son(s). Is she "Claiming the Canaanite Woman's Wisdom and Authority," as Klancher suggests in the sub-heading? Certainly she writes in the first person. In the 
tradition of allegory, she, herself, wishes to be under the table, i.e., within the holy church, and so able, along with the priests who are also there, to gather the crumbs of spiritual intelligence for herself and her son William. The use of Matt 15 is, however, only one in a virtual tapestry of texts that Dhuoda employs. Whether she "internalizes" or simply uses the Canaanite as one rhetorical tool among her many "elegant literary devices" is, I think, a question to be asked. But she is certainly a mother who, powerless herself, is seeking a way of helping her child(ren), and taking the only initiative available.

Klancher has a keen eye for the ways in which gender is used, misused or glossed over in the text's ongoing interpretive tradition, noting how in the early period the "typological, allegorical or corporate representations" of biblical characters, whether male or female, were treated as "examples of a generically male humanity" (I I 3 ), and how the Canaanite herself frequently became "little more than a trope for aspects of the (male) Christian soul" (I 36). It then comes as a surprise when, from her prodigious archival foraging, she produces a mystery play by a sixteenth-century Portuguese poet and playwright, Gil Vicente, written for a female convent audience, in which the Canaanite is heard delivering a plea specifically on the grounds that she is a woman, reminding Jesus that he was born of a woman. Gender matters here, as it does in the next section, which discusses several works in the querelle de femmes tradition, including the contribution by Suor Arcangela Tarabotti, a hard-hitting seventeenth-century Venetian nun, in whose rebuttal of an earlier Mulieres homines non esse pamphlet the Canaanite becomes not only "a symbol of virtue in all women" but "one of an army of strong and virtuous women" (1 32-33). The Vicente and Tarabotti readings not only indicate the wide range of material accessed but their liveliness adds a certain frisson to this careful academic work. The Female Other section then moves on to the Lectures by the I 9 th-century Nonconformist preacher William Jay who does indeed "tame" the Canaanite, and certainly Tarabotti's Canaanite, by aligning her with the Methodist ideal of "pious domesticity" (I4I). In another leap, both of time and genre, brief considerations of five contemporary online discussions then follow. Was this because the web is seen as addressing a wider audience, tying in more with the paranetic ethos? The progression of the gender-focused trajectory has been dramatic, but I was left wondering how representative were the more recent examples.

I think there is, more generally, a question to be asked of some of the choices of material. Why the preponderance of Protestants among the later 
writers? Why are the online contributors all male? And I miss more consideration of the work of contemporary feminist writers, such as Sharon Ringe and Elaine Wainwright and many others who have written on the Canaanite. There is admittedly a word limit for theses, but in a revision?

A curious formal feature of this work is that the chapters are not numbered, although Klancher herself consistently refers to them by number. I found this confusing, with the further complication that the section "Sermons and Homilies" appears separately in the Contents Page, and has its own pages' Header ( $82-\mathrm{IOO})$, yet, according to Klancher's notes on the Organization of Readings (39-40), it belongs within chapter 2, and indeed ends with chapter 2's Conclusion (IOO-IOI).

The number of reception history studies continues to multlply. What Klancher adds to the field is not simply yet another study, but one focused on a significant aspect, "the construction of Christian Identity," an exploration that she undergirds with a clearly articulated reception theory. She has indeed illustrated the way in which reception history is able to describe and reveal "the malleable utility of biblical exegesis though complex and diverse genealogies of the cultural norms - in this case, normative Christian identities" (286). On the way, I was delighted to meet ancient authors, many of whom I had never met before. If, at times, I wished for a less formal style, there were places where the wording was delightfully evocative, as in her description of Calvin's more intellectual approach being "as though he has pinned the Canaanite woman, like a moth, to the wall for study" (2 I9). There was a sense of watching Christian forebear after Christian forebear, each with pen in hand, gazing in pastoral or theological concern at the textual Canaanite before setting her to work upon the reader. But was she tamed? Perhaps the diversity of uses illustrates how she forever eludes taming!

Judith E. McKinlay

Dunedin 